\title{
Short communication: Physiological response to drought in North Sulawesi (Indonesia) local rice (Oryza sativa) cultivars at the tissue level in hydroponic culture
}

\author{
SONG AI NIO ${ }^{1, \vartheta}$, RISA JUNITA MEREH ${ }^{1, v \vee}$, DANIEL PETER MANTILEN LUDONG \\ ${ }^{1}$ Department of Biology, Faculty of Mathematics and Natural Sciences, Universitas Sam Ratulangi. Jl. Kampus Unsrat, Manado 95115, North Sulawesi, \\ Indonesia. Tel./fax.: +62-431-864386, "email: niosongai@unsrat.ac.id,"v ryunita_11@yahoo.com \\ ${ }^{2}$ Department of Agricultural Technology, Faculty of Agriculture, Universitas Sam Ratulangi. Jl. Kampus Unsrat, Manado 95115, North Sulawesi, \\ Indonesia. ${ }^{\circ}$ email: daniel.ludong@unsrat.ac.id
}

Manuscript received: 9 November 2020. Revision accepted: 9 December 2020.

\begin{abstract}
Nio SA, Mereh RJ, Ludong DPM. 2021. Short communication: Physiological response to drought in North Sulawesi (Indonesia) local rice (Oryza sativa) cultivars at the tissue level in hydroponic culture. Biodiversitas 22: 58-64. Water availability influenced the metabolism processes in the plants and this condition could change water balance in the cells as well as restricting the growth and production of crops. This study aimed to evaluate the effect of in vitro polyethylene glycol (PEG) 8000-induced water deficit on the relative water content and chlorophylls (total, a, and b) concentration as physiological response in leaf segments of North Sulawesi (Indonesia) local rice cultivars (cvs. Superwin, Ombong, Burungan, and Temo). The rice leaves were cut into $1 \mathrm{~cm} x 1 \mathrm{~cm}$ segments and were treated under both control $(0 \mathrm{MPa})$ and water deficit $(-0.25$ and $-0.5 \mathrm{MPa})$ using PEG 8000 as osmoticum. The experiment was factorial completely randomized block design with 4 sampling times $(0,4,8$, and 12 hours) and three replicates. Interaction of water deficit duration and PEG 8000 treatment resulted in a significant difference in leaf relative water content. The leaf relative water content at PEG $0.5 \mathrm{MPa}$ after 8 and 12 hours of treatments was lower than at control (PEG $0 \mathrm{MPa}$ ) when the treatment commenced (0 hour). The concentration of chlorophylls (total, a, and b) were significant differences among cultivars and water deficit durations. This study showed that leaf relative water content was a potential physiological indicator of PEG 8000-induced water deficit in North Sulawesi local rice at the tissue level in hydroponic culture.
\end{abstract}

Keywords: Chlorophyll, drought, local rice, relative water content

\section{INTRODUCTION}

The effort to fulfill food requirements for Indonesian inhabitants was inhibited by the decreased crop production that was caused by some factors and one of them was drought stress. The drought stress resulted in complex effects on various economic and agricultural sectors (Vangelis et al. 2011). Rice was a food source for $95 \%$ Indonesian population. Rice consumption of the Indonesian population was twice higher than the average world rice consumption, i.e. $139 \mathrm{~kg}$ per year (Setiawan et al. 2016). The effect of drought in the agriculture was related to the low water availability in the soil as a result of evapotranspiration in the root area that affected the growth and production of rice plants (Tubur 2012).

One of the agricultural development targets in Indonesia is increasing national food security and selfsufficiency. Indonesia has not been able to fulfill the requirement of total rice consumption; therefore Indonesia government still imports rice. North Sulawesi is potential as the center of rice cultivation for improving rice production (Office of Agriculture and Animal Husbandry of North Sulawesi 2011). The information on drought tolerance as well as other tolerance upon the other abiotic stress in North Sulawesi local rice is required for supporting the food security program organized by the Indonesian Ministry of Agriculture.

Drought stress affected the division, elongation, and differentiation of cells because of turgor loss, disarranged enzymes activities, and reduced energy supply from photosynthesis. Drought also resulted in electrolyte leakage, destructed solute normal transportation, accumulated reactive oxygen species (ROS), and disarranged photosynthesis reaction (Jothimani and Arulbalachandran 2020). The drought stress in this study was a water deficit induced by polyethylene glycol (PEG) 8000 as osmoticum. PEG is a group of neutral osmotically active polymers unit that is most frequently used as water inhibiting agent without toxic or detrimental effect to plant (Khalid et al. 2010; Jothimani and Arulbalachandran 2020). The dissolved PEG in water resulted in water molecules $\left(\mathrm{H}_{2} \mathrm{O}\right)$ were attracted to oxygen $\left(\mathrm{O}_{2}\right)$ and thus the water potential of the solution declined (Arianti 2015). Therefore, PEG was able to decrease the water potential in the medium as well as the decrease in soil water potential and then PEG could be used to induce plant water deficit in in vitro culture (Kumar et al. 2011). PEG 8000-induced-water deficit at water potential (WP) $0,-0.25,-0.5,-0.75$, and -1.0 $\mathrm{MPa}$ were applied in rice at the germination phase (Ballo et al. 2012). The study on water deficit induced by PEG 8000 at WP $0,-0.5$, and -1.0 MPa in rice cv. Serayu and IR 64 at 
the vegetative phase showed the dried and rolled leaves as well as brown stems as response to water deficit and commenced at WP -0.5 MPa (Banyo et al. 2013). PEG 8000 -induced water deficit at WP -0.25 and $-0.5 \mathrm{MPa}$ decreased the concentration of leaf total chlorophyll and chlorophyll a in rice cv. Superwin, Ombong, Burungan, and Temo at the whole plant level (Nio et al. 2019).

Leaf segments and discs had been used as an experimental model to evaluate the physiological changes as a response to PEG- induced-water deficit at the tissue level. Nio et al. (2011) used PEG 8000 nutrient solution at WP $0,-0.5,-1.0$, and $-1.5 \mathrm{MPa}$ and five sampling times, i.e. $0,12,24,48$, and 72 hours in wheat leaf segments. The relative water content at PEG $0 \mathrm{MPa}$ increased gradually from 0 to 72 hours after treatment and then decreased slightly at PEG $-0.5 \mathrm{MPa}$. The relative water content at PEG $0 \mathrm{MPa}$ was about $95-99 \%$ at $0-72$ hours and then slightly decreased to $88 \%$ at PEG $-0.5 \mathrm{MPa}$ at 72 hours after treatment. Nio et al. (2018) reported that leaf RWC was a parameter used to observe the physiological response to drought in plants as it was able to indicate plant water status under drought stress. Gibon et al. (2000) also reported that chlorophyll content decreased in leaf discs of Brassica napus under PEG 6000-induced water deficit at WP $-3 \mathrm{MPa}$ for 24 hours.

The objective of this study was to evaluate the physiological characteristics (relative water content and chlorophyll concentration) in leaf segments of North Sulawesi local rice cultivars (Superwin, Ombong, Burungan, and Temo) under PEG 8000-induced water deficit with media water potential (WP) $0,-0.25$ and -0.5 $\mathrm{MPa}$. This in vitro experimental method at the tissue level within a short period will be useful for screening droughttolerant rice cultivars.

\section{MATERIALS AND METHODS}

\section{Procedures}

This study was conducted in Manado, North Sulawesi, Indonesia from December 2017 to March 2018 and evaluated the drought tolerance of North Sulawesi local rice cultivars using the segments of four-fully expanded leaves. The factorial experiment in Completely Randomized Block Design consisted of four rice cultivars (Superwin, Ombong, Burungan, and Temo), three water deficit-induced PEG 8000 treatments (PEG 0, -0.25, and $0.5 \mathrm{MPa})$, and four sampling times $(0,4,8$, and 12 hours $)$ with three replicates. The water deficit treatments induced by PEG 8000 at water potential (WP) $0,-0.25$ dan -0.5 $\mathrm{MPa}$. The media were prepared by adding 0,135 , and 198 g PEG 8000 in 1 L basal medium solution (Nio et al. 2011). The AB Mix Minimax ${ }^{\circledR}$ hydroponics nutrition solution that contained calcium nitrate $\left(\mathrm{Ca}\left(\mathrm{NO}_{3}\right)_{2}\right)$, potassium nitrate $\left(\mathrm{KNO}_{3}\right)$, potassium dihydrogen phosphate $\left(\mathrm{KH}_{2} \mathrm{PO}_{4}\right)$, ammonium sulfate $\left(\left(\mathrm{NH}_{4}\right)_{2} \mathrm{SO}_{4}\right)$, potassium sulfate $\left(\mathrm{K}_{2} \mathrm{SO}_{4}\right)$, magnesium sulfate $\left(\mathrm{MgSO}_{4}\right)$, dan chelated nutrient mixture was used as the basal medium in this study (Nio et al. 2019).
The rice seeds were selected by immersing them in the water for 2-3 hours. The selected seeds were surfacedsterilized using $0.1 \% \mathrm{NaOCl}$ solution three times and each time for 2 minutes, then the seeds were rinsed with water. The seeds were germinated and the germinated seeds were grown in the plastic containers with media (the mixture of $6 \mathrm{~g}$ NPK fertilizer in $7 \mathrm{~kg}$ soil) and maintained by watering them with $0.1 \%$ Gandasil $\mathrm{D}^{\circledR}$ (fertilizer) solution every second day until the plants reached four-fully-expanded leaf stage (modification Nio and Ludong 2014).

Leaf samples were collected and rinsed with $0.5 \mathrm{mM}$ $\mathrm{CaSO}_{4}$ solution, then cut into $1 \mathrm{~cm} \times 1 \mathrm{~cm}$ segments and immersed in the basal media. The leaf segments were transferred into $200 \mathrm{~mL}$ plastic containers (sealed with cling wrap plastic) and incubated in $100 \mathrm{~mL}$ basal media for 24 hours. After 24 hours, the leaf segments were immediately transferred into the plastic containers and incubated in $100 \mathrm{~mL}$ basal media added with PEG 8000 solution depending on the treatments (PEG 0, -0.25, and $0.5 \mathrm{MPa}$ ). These media water potential used in this study were categorized as medium level $(-0.25 \mathrm{MPa})$ and high level (-0.5 MPa) of drought stress (Pharmawati et al. 2017). All plastic containers with leaf segments were put on a rotary shaker (50 opm) under 12 hour-continuous light (cool white 36 Watt, 2880 lumen) per day in a $25^{\circ} \mathrm{C}$ room (modification Nio et al. 2011). Samples were collected at selected times, depending on the treatments as described below in Table 1 .

The leaf relative water content (RWC) was calculated as RWC $(\%)=100 \mathrm{x}$ (fresh mass - dry mass)/(turgid mass dry mass) (Nio et al. 2011). The extraction of leaf chlorophyll was carried out using 95\% ethanol and the concentration of chlorophylls (total, a, and b) were calculated based on the optical density measured by spectrophotometer SP-3000 nano Optima ${ }^{\circledR}$ at $\lambda 649$ and $665 \mathrm{~nm}$ (Tjolleng et al. 2019).

\section{Data analysis}

Microsoft Office Excel 2010 was used to calculate mean and standard errors. SPSS 16 was used to analyze the data. Analysis of variance (ANOVA) followed by Duncan's Multiple Range Test (DMRT) 5\% was used to identify any significant differences among the treatments (where $\mathrm{p}<0.05$ ).

Table 1. Sampling times of leaf segments under PEG 8000induced water deficit $(\checkmark)$

\begin{tabular}{ccccc}
\hline PEG & & \multicolumn{3}{c}{ Hours } \\
\cline { 2 - 5 } (MPa) & $\mathbf{0}$ & $\mathbf{4}$ & $\mathbf{8}$ & $\mathbf{1 2}$ \\
\hline & & & & \\
0 & $\checkmark$ & $\checkmark$ & $\checkmark$ & $\checkmark$ \\
-0.25 & & $\checkmark$ & $\checkmark$ & $\checkmark$ \\
-0.50 & & $\checkmark$ & $\checkmark$ & $\checkmark$ \\
& & & & \\
\hline
\end{tabular}




\section{RESULTS AND DISCUSSION}

\section{Leaf relative water content as a response to PEG 8000 - induced water deficit}

The result of ANOVA revealed that treatment duration, PEG 8000 treatment, and interaction between treatment duration and PEG 8000 treatment resulted in significant differences in leaf relative water content. On the other hand, cultivars, the interaction between cultivar and treatment duration, interaction between cultivar and PEG 8000 treatment as well as interaction among cultivar, treatment duration, and PEG 8000 treatment did not result in any significant difference in leaf RWC (Figure 1). The lowest leaf RWC was observed at PEG -0.5 MPa for 8 and 12 hours of treatment, whereas the highest RWC was at PEG $0 \mathrm{MPa}$. Leaf RWC in PEG $-0.5 \mathrm{MPa}$ at 8 hours $(68.34 \%)$ and 12 hours after treatment $(68.21 \%)$ were $32.18 \%$ and $31.92 \%$ lower $(\mathrm{p}<0.05)$ than in PEG $0 \mathrm{MPa}$ (control) at 0 hour $(90.16 \%)$, respectively (Table 2 ).

The same result was reported in leaf segments of wheat (Triticum aestivum L.) under PEG 8000-induced water deficit for 12, 24, 48, and 72 hours. Leaf RWC in PEG 0 $\mathrm{MPa}$ was $95-99 \%$ at $0-72$ hours after treatment and then decreased to $88 \%$ in PEG $-0.5 \mathrm{MPa}$ at 72 hours after treatment. It was reported that RWC was lower in the medium with more negative water potential (Nio et al. 2011). Water deficit induced by PEG 6000 at $-1.22 \mathrm{MPa}$ in pigeonpea (Cajanus cajan (L.) Millsp.) also resulted in a decrease of 25 and $56 \%$ of RWC in 26 and 46-day-old leaves, respectively (Kumar et al. 2011). Jothimani and Arulbalachandran (2020) reported that RWC in 25-day-old seedlings of black gram (Vigna mungo L.) at $20 \%$ of PEG $6000(75.14 \%)$ was $12 \%$ lower than control $(84.27 \%)$ This present study showed that leaf RWC was a suitable indicator of drought stress in leaf segments of rice cv. Superwin, Ombong, Burungan, and Temo because the longer duration and the more negative water potential of PEG 8000 treatment decreased leaf RWC.

The concentration of leaf chlorophylls (total, a, and b) as a response to PEG 8000-induced water deficit

Chlorophyll concentration was positively correlated with photosynthesis capacity as well as plant production (Kristanto et al. 2014). The chlorophyll formation was optimal when water availability supported the physiological response (Prihastanti 2010). The normal metabolic activity and nutrients absorption as well as leaf chlorophyll formation were inhibited under drought (Banyo et al. 2013). The chlorophyll concentration declined under drought due to the slow chlorophyll synthesis, fast chlorophyll breakdown, unstable protein complexes, and the chlorophyll destruction by elevated activity of chlorophyll degrading enzymes, such as chlorophyllase (Akram et al. 2013; Amini et al. 2013).

Factors of cultivar and treatment duration resulted in a significant difference in the concentration of total chlorophyll in rice (cvs. Superwin, Ombong, Burungan, and Temo) leaf segments under PEG 8000-induced water deficit (Figure 2). The concentration of total chlorophyll in cv. Temo $\left(6.16 \mathrm{mg} \mathrm{L}^{-1}\right)$ was 57 and $121 \%$ higher $(\mathrm{p}<0.05)$ than in cv. Burungan (3.92 $\left.\mathrm{mg} \mathrm{L}^{-1}\right)$ and Superwin $(2.78 \mathrm{mg}$ $\left.\mathrm{L}^{-1}\right)$, respectively. The concentration of total chlorophyll decreased until 12 hours after treatment. The concentration of total chlorophyll at 0 hour $\left(6.10 \mathrm{mg} \mathrm{L}^{-1}\right)$ was 59 and $64 \%$ larger $(\mathrm{p}<0.05)$ than at 8 hours $(3.82 \mathrm{mg} \mathrm{L}-1)$ and 12 hours $\left(3.72 \mathrm{mg} \mathrm{L}^{-1}\right)$ after treatment, respectively (Table 2). Some previous studies reported the content of leaf chlorophyll as a physiological response to drought. PEG6000-induced-water deficit at $-1.22 \mathrm{MPa}$ significantly reduced the concentration of total chlorophyll in young and old leaves of pigeon pea (Kumar et al. 2011). The content of total chlorophyll in rice cv. IR 64 under PEG -1.0 MPa (13.0 $\mathrm{mg} \mathrm{L}^{-1}$ ) was smaller than under PEG $0 \mathrm{MPa}$ or control (24.7 mg L $\mathrm{m}^{-1}$ ) for 3 weeks (Nio 2010). The concentration of leaf chlorophyll total was potential physiological indicators for water deficit induced by PEG 8000 in North Sulawesi local rice (cv. Superwin, Ombong, Temo, and Burungan) as the concentration of total chlorophylls decreased as a response to this treatment (Nio et al. 2019).

Table 2. The relative water content, the concentration of total chlorophyll, chlorophyll a and b in leaves of rice cv. Superwin, Ombong, Temo, and Burungan at 0, 4, 8, and 12 hours after PEG8000 -induced water deficit (WP $0,-0.25$, and $-0.5 \mathrm{MPa}$ ). Values are mean $\pm \operatorname{SE}(n=3)$

\begin{tabular}{|c|c|c|c|c|}
\hline Factors & $\begin{array}{c}\text { Relative } \\
\text { water } \\
\text { content } \\
(\%)\end{array}$ & $\begin{array}{c}\text { Total } \\
\text { chlorophyll } \\
\left(\mathrm{mg} \mathrm{L}^{-1}\right)\end{array}$ & $\begin{array}{c}\text { Chlorophyll } \\
\text { a } \\
\left(\mathrm{mg} \mathrm{L}^{-1}\right)\end{array}$ & $\begin{array}{c}\text { Chlorophyll } \\
\text { b } \\
\left(\mathrm{mg} \mathrm{L}^{-1}\right)\end{array}$ \\
\hline \multicolumn{5}{|l|}{ Cultivar } \\
\hline Superwin & & $2.78 \pm 0.22^{\mathrm{a}}$ & $2.66 \pm 0.15^{\mathrm{a}}$ & $2.09 \pm 0.19^{a}$ \\
\hline Ombong & & $5.44 \pm 0.39^{\mathrm{bc}}$ & $3.59 \pm 0.20^{\mathrm{b}}$ & $2.95 \pm 0.23^{\mathrm{b}}$ \\
\hline Burungan & & $3.92 \pm 0.38^{\mathrm{ab}}$ & $2.79 \pm 0.16^{\mathrm{a}}$ & $2.12 \pm 0.20^{\mathrm{a}}$ \\
\hline Temo & & $6.16 \pm 0.49^{c}$ & $3.91 \pm 0.28^{\mathrm{b}}$ & $3.42 \pm 0.37^{\mathrm{b}}$ \\
\hline \multicolumn{5}{|c|}{ Time (hours) } \\
\hline 0 & $90.16 \pm 1.05^{b}$ & $6.10 \pm 0.65^{b}$ & $4.35 \pm 0.27^{b}$ & $3.60 \pm 0.31^{\mathrm{c}}$ \\
\hline 4 & $86.52 \pm 1.59^{b}$ & $4.67 \pm 0.45^{\mathrm{ab}}$ & $3.13 \pm 0.18^{a}$ & $2.75 \pm 0.26^{\mathrm{b}}$ \\
\hline 8 & $77.78 \pm 2.65^{\mathrm{a}}$ & $3.82 \pm 0.26^{\mathrm{a}}$ & $2.87 \pm 0.14^{\mathrm{a}}$ & $2.13 \pm 0.16^{\mathrm{a}}$ \\
\hline 12 & $78.44 \pm 2.67^{\mathrm{a}}$ & $3.72 \pm 0.44^{\mathrm{a}}$ & $2.61 \pm 0.17^{\mathrm{a}}$ & $2.10 \pm 0.23^{\mathrm{a}}$ \\
\hline \multicolumn{5}{|l|}{ PEG (MPa) } \\
\hline 0 & $89.51 \pm 0.81^{\mathrm{c}}$ & & & \\
\hline-0.25 & $82.77 \pm 1.90^{\mathrm{b}}$ & & & \\
\hline-0.50 & $77.40 \pm 2.48^{\mathrm{a}}$ & & & \\
\hline \multicolumn{5}{|l|}{ Time; PEG } \\
\hline $0 ; 0$ & $90.16 \pm 2.00^{\mathrm{f}}$ & & & \\
\hline $0 ;-0.25$ & $90.16 \pm 2.00^{\mathrm{f}}$ & & & \\
\hline $0 ;-0.50$ & $90.16 \pm 2.00^{f}$ & & & \\
\hline $4 ; 0$ & $91.42 \pm 0.82^{\mathrm{f}}$ & & & \\
\hline $4 ;-0.25$ & $87.71 \pm 1.04^{\mathrm{e}}$ & & & \\
\hline $4 ;-0.50$ & $80.79 \pm 2.13^{\mathrm{d}}$ & & & \\
\hline $8 ; 0$ & $88.25 \pm 1.13^{\mathrm{e}}$ & & & \\
\hline $8 ;-0.25$ & $74.83 \pm 2.66^{\mathrm{b}}$ & & & \\
\hline $8 ;-0.50$ & $68.34 \pm 3.23^{\mathrm{a}}$ & & & \\
\hline $12 ; 0$ & $88.19 \pm 2.01^{\mathrm{e}}$ & & & \\
\hline $12 ;-0.25$ & $78.38 \pm 2.54^{\mathrm{c}}$ & & & \\
\hline $12 ;-0.50$ & $68.21 \pm 2.26^{\mathrm{a}}$ & & & \\
\hline
\end{tabular}

Note: Different letters in the same column indicated the significant difference $(p<0.05)$ amongst the treatments based on DMRT $5 \%$. 
The concentration of leaf chlorophyll-a was significant different among the cultivars and among the treatment durations (Figure 3). The concentration of chlorophyll-a in cv. Burungan $\left(2.79 \mathrm{mg} \mathrm{L}^{-1}\right)$ and Superwin $\left(2.66 \mathrm{mg} \mathrm{L}^{-1}\right)$ was 40.08 and $46.98 \%$ smaller $(p<0.05)$ than in $\mathrm{cv}$. Temo (3.91 $\left.\mathrm{mg} \mathrm{L}^{-1}\right)$, respectively. The concentration of chlorophyll-a declined gradually until 12 hours after treatment. The concentration of chlorophyll-a at 4 hours (3.13 $\left.\mathrm{mg} \mathrm{L}^{-1}\right), 8$ hours $\left(2.87 \mathrm{mg} \mathrm{L}^{-1}\right)$, and 12 hours $(2.61 \mathrm{mg}$ $\left.\mathrm{L}^{-1}\right)$ after treatment were 39,51 , and $65 \%$ smaller $(\mathrm{p}<$ 0.05 ) than at 0 hours $\left(4.35 \mathrm{mg} \mathrm{L}^{-1}\right)$, respectively (Table 2). Several previous studies were conducted to evaluate leaf chlorophyll-a, such as in 40-day-old-peanut seedlings under PEG $6000(5,10,15$, and 20\%) for 24 hours (Shivakrishna et al. 2018), North Sulawesi local rice (cvs. Superwin, Ombong, Temo, and Burungan) under PEG 8000-induced water deficit for 12 hours (Nio et al. 2019), and 25-day-old black gram (Vigna mungo (L.) Hepper) seedlings under PEG 6000 (5, 10, and 20\%) for three days (Jothimani and Arulbalachandran 2020). The concentration of leaf chlorophyll-a in peanut seedlings declined with increasing concentration of PEG 6000 (Shivakrishna et al. 2018). PEG 8000-induced water deficit for 12 hours reduced the concentration of leaf chlorophyll-a in North Sulawesi local rice cultivars (Nio et al. 2019). The concentration of leaf chlorophyll-a in black gram seedlings declined with increasing PEG 6000 concentration and the maximum decrease was observed at $20 \%$ of PEG (Jothimani and Arulbalachandran 2020).

The chlorophyll-b concentration was significantly different among the cultivars and the treatment durations
(Figure 4). The concentration of chlorophyll-b in cv. Superwin (2.09 $\left.\mathrm{mg} \mathrm{L}^{-1}\right)$ and Burungan $\left(2.12 \mathrm{mg} \mathrm{L}^{-1}\right)$ were lower than in cv. Ombong (2.95 $\left.\mathrm{mg} \mathrm{L}^{-1}\right)$ and Temo (3.42 $\left.\mathrm{mg} \mathrm{L}^{-1}\right)$. The concentration of chlorophyll-b at $0,4,8$, and 12 hours of treatment was $3.60,2.75,2.13$, and $2.10 \mathrm{mg} \mathrm{L}^{-}$ ${ }^{1}$, respectively, however, it was not significantly different between 8 and 12 hours of treatment. The concentration of chlorophyll-b at 4, 8, and 12 hours was 30, 69, and $71 \%$, respectively, lower than at 0 hours (Table 2). Some other experiments had been conducted to evaluate the content of chlorophyll-b under water deficit, such as in apple geranium (Khalid et al. 2010), cocoa (Prihastanti 2010), pigeon pea (Kumar et al. 2011), rice (Banyo et al. 2013), and peanut (Shivakrishna et al. 2018). The concentration of leaf chlorophyll-b in apple geranium was 0.092 and 0.046 $\mathrm{mg} \mathrm{g}^{-1}$, respectively under control and treatment of $40 \%$ field water capacity (Khalid et al. 2010). It was reported that the concentration of leaf chlorophyll $b$ in a one-yearcocoa plant at two months after watering $50 \%$ field capacity was $50 \%$ lower than watering $75 \%$ field capacity (Prihastanti 2010). The level of leaf chlorophyll-b decreased significantly under PEG 6000 nutrient solution at $-1.22 \mathrm{MPa}$ in pigeon pea (Kumar et al. 2011). The concentration of chlorophyll-b in rice at PEG -0.5 dan -1.0 $\mathrm{MPa}$ was three times higher than in PEG $0 \mathrm{MPa}$ or control (Banyo et al. 2013). The concentration of leaf chlorophyll$\mathrm{b}$ in peanut seedlings grown in the nutrient PEG 6000 solution $(5,10,15$, and $20 \%$ ) declined with increasing concentration (Shivakrishna et al. 2018).
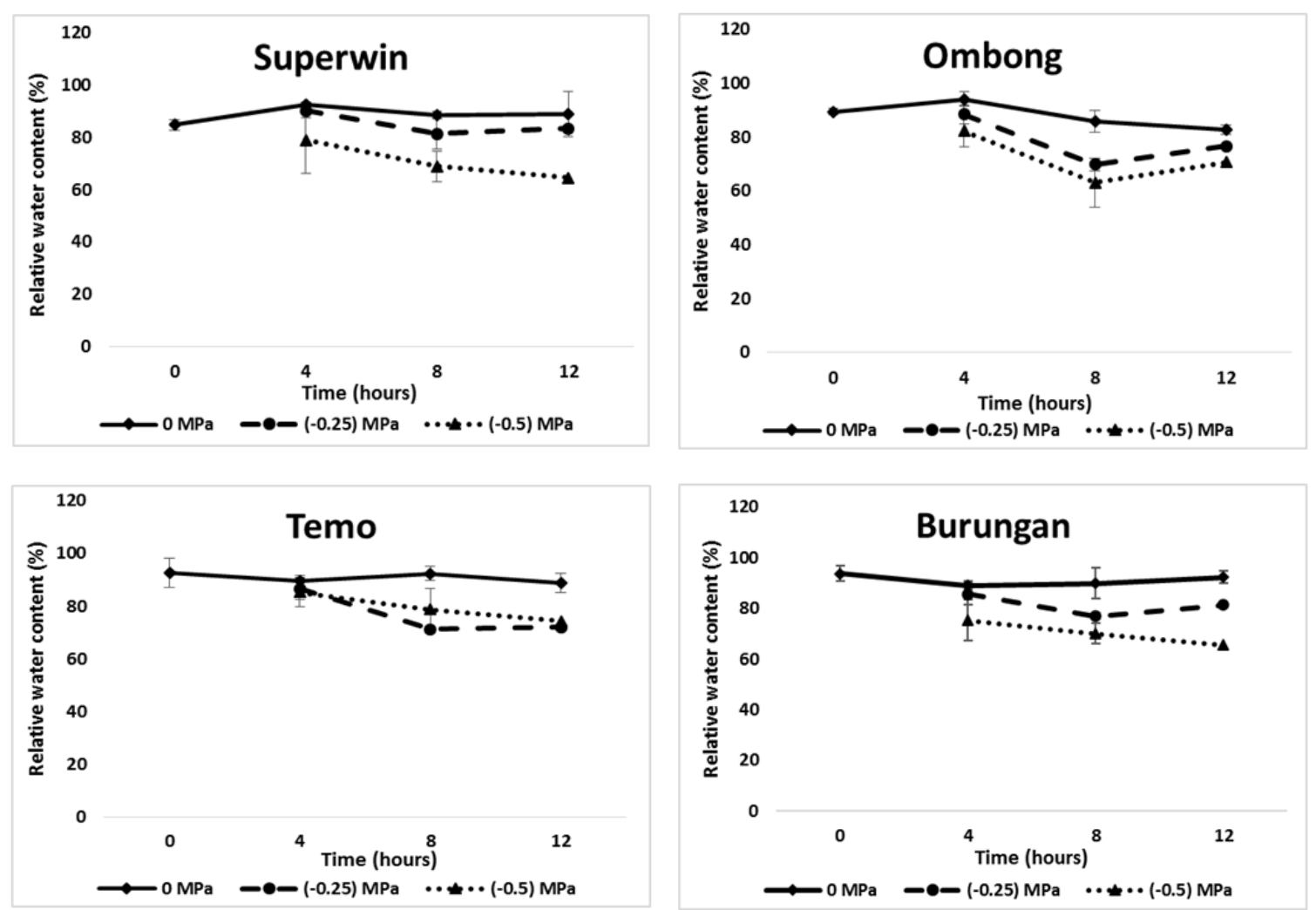

Figure 1. The leaf relative water content (mean $\pm \mathrm{SE} ; \mathrm{n}=3$ ) in rice cvs. Superwin, Ombong, Temo, and Burungan at $0,4,8$, and 12 hours after PEG-8000- induced water deficit (WP $0,-0.25$ and $-0.5 \mathrm{MPa}$ ) 

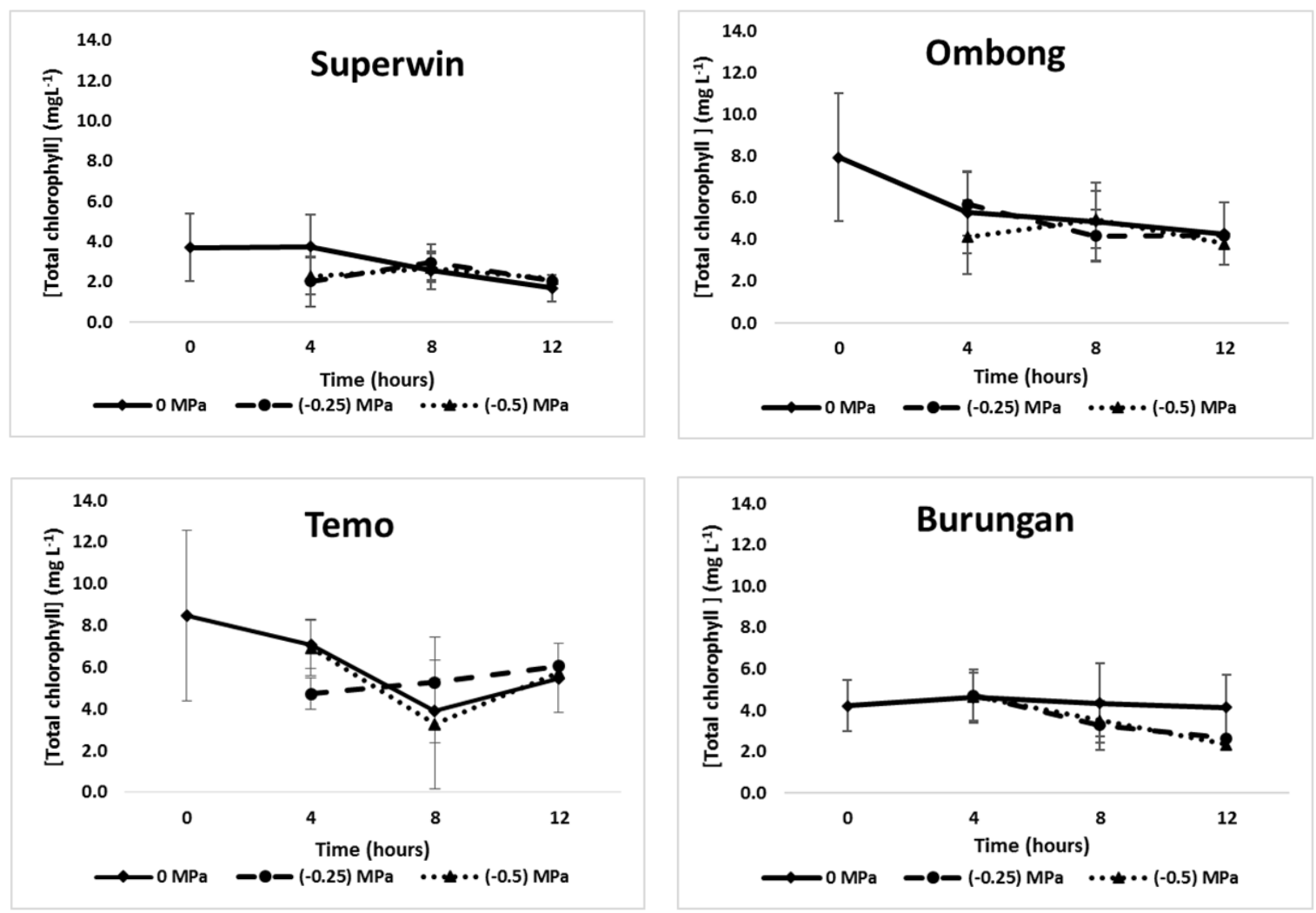

Figure 2. The concentration of leaf total chlorophyll (mean \pm SE; $n=3$ ) in rice cvs. Superwin, Ombong, Temo, and Burungan at $0,4,8$, and 12 hours after PEG-8000- induced water deficit (WP 0, -0.25 and $-0.5 \mathrm{MPa}$ )
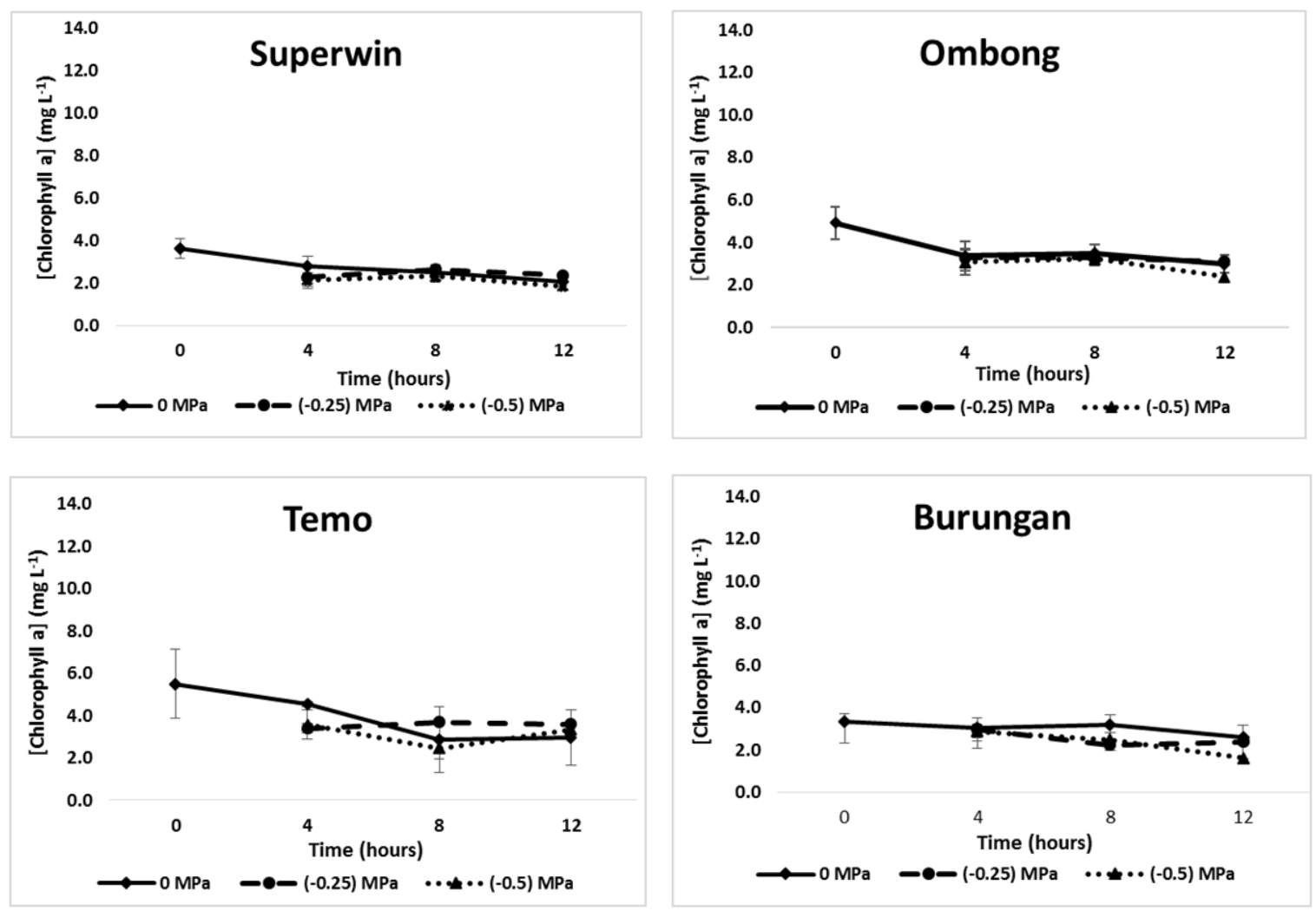

Figure 3. The concentration of leaf chlorophyll-a (mean $\pm \mathrm{SE} ; \mathrm{n}=3$ ) in rice cvs. Superwin, Ombong, Temo, and Burungan at $0,4,8$, and 12 hours after PEG-8000- induced water deficit (WP 0, -0.25 and -0.5 MPa) 

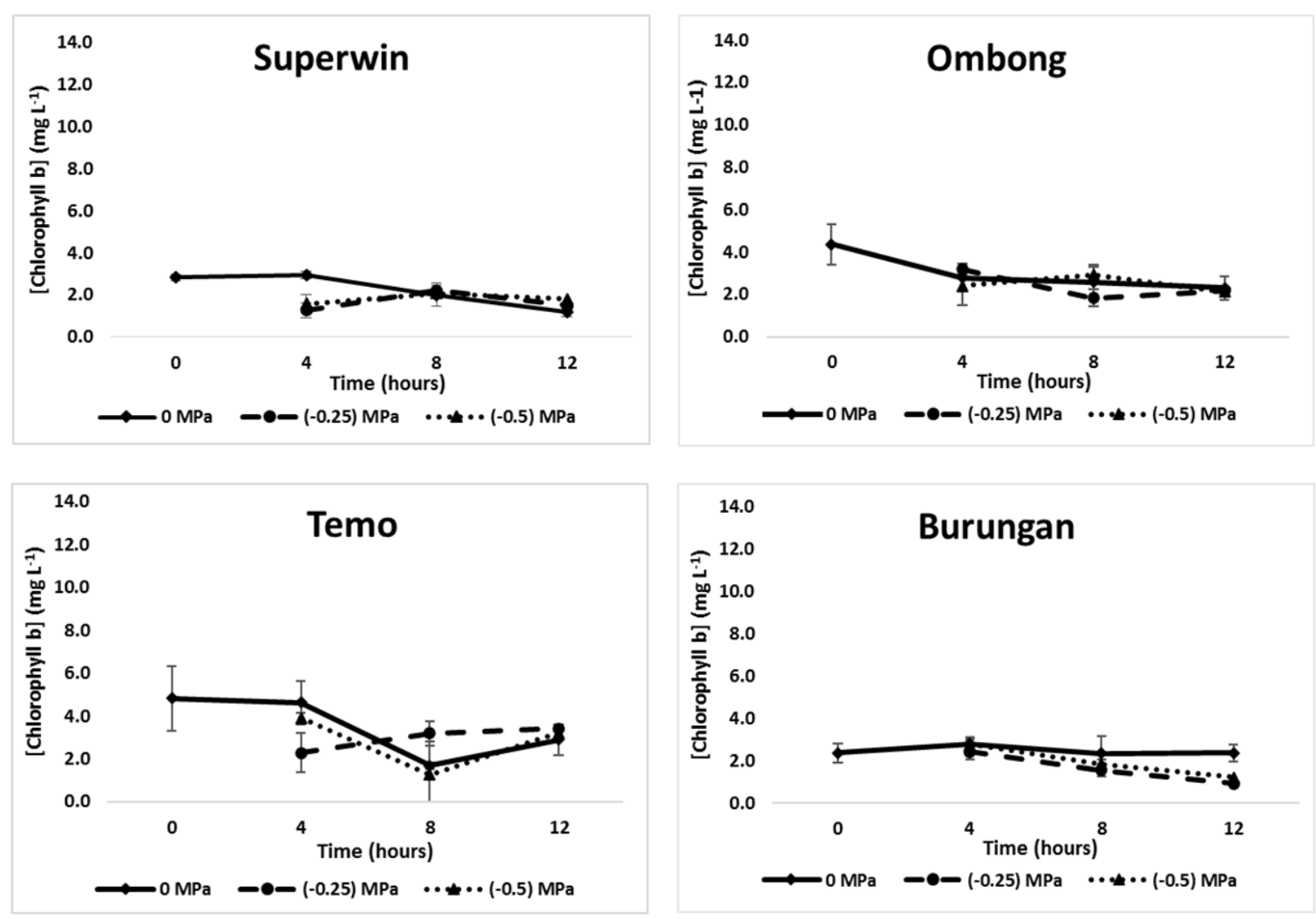

Figure 4. The concentration of leaf chlorophyll-b (mean \pm SE; $n=3$ ) in rice cvs. Superwin, Ombong, Temo, and Burungan at $0,4,8$, and 12 hours after PEG-8000- induced water deficit (WP 0, -0.25 and $-0.5 \mathrm{MPa}$ )

This present study revealed that applying PEG 8000induced-water deficit at -0.25 and $-0.5 \mathrm{MPa}$ for 4,8 and 12 hours did not decrease the concentration of chlorophylls (total, a, and b) in the leaf segments. The different response to drought in this study due to the treatment duration of water deficit was shorter (only 12 hours) and leaf segments were used instead of the whole plant (Khalid et al. 2010; Prihastanti 2010; Kumar et al. 2011; Banyo et al. 2013; Shivakrishna et al. 2018; Nio et al. 2019; Jothimani and Arulbalachandran 2020). Leaf chlorophylls concentration, therefore, was not a suitable physiological indicator of drought tolerance in North Sulawesi local rice at the tissue level in hydroponic culture.

It was concluded that leaf relative water content was a potential physiological indicator of drought tolerance in North Sulawesi local rice cvs. Superwin, Ombong, Burungan, and Temo at the tissue level (leaf segments) in hydroponic culture using PEG 8000 solution as osmoticum to reduce media water potential. Further detailed experiments are still required for screening the droughttolerant ones among these North Sulawesi local rice cultivars.

\section{ACKNOWLEDGEMENTS}

The authors are grateful to Seed Control and Certification Services Agency for Food Crops and Horticulture (Balai Pengawasan Sertifikasi Benih Tanaman
Pangan dan Hortikultura), North Sulawesi Province, Indonesia, for the seeds. Sincere thanks to Dr. Agus Darwanto, Novartis Institute for Biomedical Research, Cambridge, USA for useful suggestions on this manuscript and special thanks to Parluhutan Siahaan for assistance during the research.

\section{REFERENCES}

Akram HM, Ali A, Sattar A, Rahman HSU, Bibi A. 2013. Impact of water deficit stress on various physiological and agronomic traits of three basmati rice (Oryza sativa L.) cultivars. J Anim Plant Sci 23 (5): 1415-1423.

Amini R, Milani MA, Mohammadinasab AD. 2013. Physiological response of lentil (Lens culinaris Medick.) to water limitation affected by wheat straw mulch application. Intl J Agron Plant Prod 4 (10): 2548-2553.

Arianti AM. 2015. Effect of Various Concentrations of PEG (Polyethylene Glycol) 6000 on Callus Quality and Quantity and Quality Test of Vernodalin Secondary Metabolites on African (Vernonia amygdalina) Leaf Callus. [Thesis]. Fakultas Sains dan Teknologi, UIN Maulana Malik Ibrahim, Malang. [Indonesian].

Ballo M, Nio SA, Pandiangan D, Mantiri F. 2012. Morphological response of rice to water deficit at the germination phase. Jurnal Bioslogos 2 (2): $88-95$. DOI: $10.35799 /$ bioslogos.v2i2.1045. [Indonesian]

Banyo Y, Nio SA, Siahaan P, Tangapo A. 2013. Leaf chlorophyll content in rice under polyethylene-glycol-induced water deficit. Jurnal Ilmiah Sains 13 (1): 1-8. [Indonesian]

Office of Agriculture and Animal Husbandry of North Sulawesi. 2011. Rice field potential based on the type of irrigation in North Sulawesi. Dinas Pertanian dan Peternakan Sulawesi Utara, Manado. [Indonesian]. 
Gibon Y, Sulpice R, Larher F. 2000. Proline accumulation in canola leaf discs subjected to osmotic stress is related to the loss of chlorophylls and to the decrease of mitochondrial activity. Physiol Plant 110 (4) 469-476. DOI: 10.1111/j.1399-3054.2000.1100407.x

Jothimani K, Arulbalachandran D. 2020. Physiological and biochemical studies of black gram (Vigna mungo (L.) Hepper) under polyethylene glycol induced drought stress. Biocatal Agric Biotechnol 29: 101777. DOI: $10.1016 /$ j.bcab.2020.101777

Khalid KA, da Silva JAT, Cai W. 2010. Water deficit and polyethylene glycol 6000 affects morphological and biochemical characters of Pelargonium odoratissimum (L.). Sci Hortic 125 (2): 159-166. DOI: 10.1016/j.scienta.2010.03.009

Kristanto BA, Indradewa D, Ma'as A, Sutrisno RD. 2014. Lea senescence, leaf chlorophyll content and grain yield in sweet sorghum (Sorghum bicolor L. Moench) under water-stressed condition. AgroUPY 6 (1): 38-49. [Indonesian].

Kumar RR, Karajoi K, Naik GR. 2011. Effect of polyethylene glyco induced water stress on physiological and biochemical responses in pigeonpea (Cajanus cajan L. Millsp.). Recent Res Sci Technol 3 (1): $148-152$.

Nio SA. 2010. Evaluation of concentration of total chlorophyll, chlorophyll $\mathrm{a}$ and $\mathrm{b}$ in leaves as indicators of water deficit in rice (Oryza sativa L.). Jurnal Ilmiah Sains 10 (1): 86-90.

Nio SA, Colmer TD, Wade LJ, Cawthray G. 2011. Osmotic adjustment and solutes accumulation in leaves of wheat (Triticum aestivum L.) during water deficit. J Math Sci 16: 43-48.

Nio SA, Ludong DPM. 2014. Comparing the drought tolerance of local rice cultivar Superwin with other cultivars in North Sulawes Province based on dry matter partitioning. Proc Intl Conf Glob Resour Conserv 4 (1): 17-22.
Nio SA, Ludong DPM, Wade LJ. 2018. Comparison of leaf osmotic adjustment expression in wheat (Triticum aestivum L.) under water deficit between the whole plant and tissue levels. Agric Nat Res 52: 33-38.

Nio SA, Pirade M, Ludong DPM. 2019. Leaf chlorophyll content in North Sulawesi (Indonesia) local rice cultivars subjected to polyethylene glycol (PEG) 8000-induced water deficit at the vegetative phase. Biodiversitas 20 (9): 2462-2467. DOI: 10.13057/biodiv/d200905.

Pharmawati M, Wirasiti NN, Wrasiati LP. 2017. Morphological responses and aquaporin gene expression in rice IR64 under drought stress at the reproductive stage. Jurnal Bios Logos 7 (2): 60-65.

Prihastanti E. 2010. The chlorophyll concentration and growth of cocoa (Theobroma cacao) sprout under different water deficit levels. Jurnal Bioma 12 (2): 35-39. [Indonesian].

Setiawan A. 2016. Consumer behavior in purchasing organic rice. [Thesis]. Fakultas Pertanian Universitas Lampung, Bandarlampung.

Shivakrishna P, Reddy AK, Rao MD. 2018. Effect of PEG-6000 imposed drought stress on RNA content, relative water content (RWC), and chlorophyll content in peanut leaves and roots. Saudi J Biol Sci 25: 285-289.

Tjolleng F, Siahaan P, Nio SA. 2019. The level of leaf total chlorophyll in North Sulawesi local rice under partial submergence. Jurnal MIPA UNSRAT Online 8 (2):51-54. [Indonesian].

Tubur HW, Chozin MA, Santosa E, Junaedi A. 2012. Agronomic responses of low land rice varieties to drought periods. J Agron Indonesia 40 (3): 167-173.

Vangelis H, Spiliotis M, Tsakiris G. 2011. Drought severity assessment based on the bivariate probability analysis. Water Res Manag 2 (5): 357-371. 